\title{
Migration, TiEd Foreign Aid AND THE WELFARE STATE
}

\author{
PANOS HATZIPANAYOTOU \\ MICHAEL S. MICHAEL
}

\author{
CESIFO WORKING PAPER No. 1497 \\ CATEGORY 1: PUBlic FinANCE \\ JULY 2005 \\ Presented AT CESifo AREA CONFERENCE on \\ Public SeCtor ECONOMICS, APRIL 2005
}
An electronic version of the paper may be downloaded
- from the SSRN website:
www.SSRN.com
- from the CESifo website: www.CESifo.de




\title{
MigRATION, TIED FOREIGN AID AND THE WELFARE STATE
}

\begin{abstract}
In this paper we highlight aspects related to the links between international migration, foreign tied aid and the welfare state. We model migration as a costly movement from an aidrecipient developing country with low income, poor infrastructure, and no welfare system, towards a rich donor, developed country with a well-developed welfare system. Within this model we find, among other things, that the best response of the developed donor country is to increase aid as the co-financing rate by the recipient country increases. When the immigration cost decreases, e.g. due to greater economic integration between the two countries, it is beneficial for the donor country to increase aid.
\end{abstract}

JEL Code: F22, F35, H23.

Keywords: migration, tied foreign aid, welfare state.

Panos Hatzipanayotou

Department of International and European

Economic Studies

Athens University of Economics and Business

76 Patission str.

Athens 10434

Greece

hatzip@aueb.gr
Michael S. Michael

Department of Economics

University of Cyprus

P.O. Box 20537

Nicosia, CY1678

Cyprus

m.s.michael@ucy.ac.cy

We thank Mathias Wrede, Thomas Moutos, Apostolis Philippopoulos, and participants at the CESifo Area Conference on Public Sector Economics, April 2005, for useful comments and suggestions. For remaining shortcomings the authors are solely responsible. 


\section{Introduction}

In recent years there is a surge of migration from Eastern European and other countries towards the developed countries and the countries of the European Union in particular, despite the efforts of most host countries to restrict immigration, especially that of the low skilled labor. From 1992 to 2001 immigration rates in the EU were the highest in the world. According to Wildasin (2004), more than one million people peryear have been arriving to the EU from points of origin beyond its geographic boundaries, amounting to a cumulative inflow of over 13 million immigrants over that period. Countries, traditionally hosts of immigrants, eg., Germany, experienced a resurgent of immigration, while others, traditionally emigration countries, eg., Spain and Ireland experienced a strong immigration turnaround. On the other hand, at the recent enlargement of the EU (ie., 1.5.2004) the original 15 union members adopted various restrictions on free labor movements between them and the accession countries for a transitional time period. ${ }^{1}$ EU countries are concerned that due to the large differences in workers income, huge migration will occur and this could create problems in their labor markets and endanger their social welfare system. Governments in advanced societies impose income and other taxes to finance the provision of public goods and inputs and make transfers in money and or in kind to their citizens. Thus, the governments with their welfare systems transfer incomes from the relatively more to their less affluent citizens, amongst which are the immigrants. In particular, regarding fiscal transfers to this latter group, in a recent public policy forum, ${ }^{2}$ Wildasin (2004) notes, among other things, that in Germany, Sweden and Denmark where immigrants account for approximately 10 percent of the total population, they are recipients of over 30 percent of total cash welfare expenditures. In addition, Sinn (2004, p. 6) analyzing recent immigration flows into Germany states that: “...Migration of workers has been a direct migration into the welfare state because the migrants have less than average productivity, earn less than average wages and are therefore beneficiaries of the redistributive activities of the welfare state. They pay taxes and contributions but receive more public resources from the state than they pay for. According to a study by the Ifo Institute, in 1997 the average

\footnotetext{
${ }^{1}$ With the exception of two small countries, Cyprus and Malta.

2 The CES-ifo and BMW Foundation Herbet Quandt Munich Economic Summit on "Social Union, Migration and the Constitution: Integration at Risk", June 2004.
} 
migrant, who had been in the country for less than ten years, received a gift of about $€$ $2,400 \ldots ”$

Considering the above it can be argued that unrestrained influxes of immigrants and in particular of low-skilled workers, in host countries may exert strong pressures on the social welfare programs designed to protect low-income groups.

\section{Literature Review}

Standard neoclassical results of the international migration literature state that permanent migration is welfare beneficial to the nationals of a host country and welfare deteriorating to the non-emigrants of a source country, while marginal international labor flows have no welfare effects in either type of countries. ${ }^{3}$ These results are shown to hold irrespectively of the number of goods or factors, and of whether commodity prices are endogenously determined or exogenously fixed (eg., see Wong 1985, Quibria 1988). ${ }^{4}$

Recent developments in the literature of international migration within models which include income taxes and transfers reveal that immigration of workers, who are subject to the same fiscal treatment as natives and are net fiscal beneficiaries, reduces the welfare of natives (e.g., Wildasin 1994, Michael 2003). ${ }^{5}$ On the other hand, Razin and Sadka (2004), in an infinite-horizon, overlapping generations' economy, show that this net welfare loss due to immigration of the low-skilled labour could change to net gain to the natives. ${ }^{6}$ Razin, Sadka and Swagel (2004), using data for 11 European countries found that higher share of low-education immigrants in the population leads to a lower tax rate on labor income and less generous transfers. Most developed

\footnotetext{
${ }^{3}$ Migration is permanent in the sense that they do not remit any part of their income earnings back to the source country, and that their consumption and utility are part of the host countries welfare. Also permanent immigrants are allowed direct access to the host countries public welfare system. Other types of international migration considered in the international trade literature are temporary and crossborder migration. Kondoh (1999) examines the welfare implications of these types of migration patterns on host country welfare.

${ }^{4}$ In the above and other studies of the relevant literature, the welfare beneficial effects of migration for the host country rely on the assumption of perfectly competitive product and factor markets. Chao and $\mathrm{Yu}$ (2002) conclude that in an economy with imperfectly competitive commodity markets, immigration of unskilled workers can be welfare deteriorating while that of skilled workers can be welfare improving.

${ }^{5}$ See Sandmo and Wildasin (1999), among others, for the welfare implications of immigration and tax policies when immigrants are subject to fiscal treatment different than that of native workers.

${ }^{6}$ Epstein and Hillman (2003), in a model with unemployment due to efficiency wages, have shown how the presence of unemployed immigrants receiving tax-financed income transfers can be beneficial for both national workers and employers.
} 
countries, however, are more willing to accept immigration of high skilled workers who, among other things, are net fiscal contributors (see for example Carrington and Detragiache 1998 and Bauer and Kunze 2004).

The purpose of this paper is to highlight aspects related to the links between international migration and the welfare state. To achieve this we model migration as a costly labor movement from an aid-recipient developing country with low income, infrastructure, and a non-existing welfare system, towards a rich donor developed country with a well-developed welfare system. The developed country imposes income taxes to finance domestic income transfers and aid to the developing country. Aid to the developing country is used to finance the provision of a public input. Aid, however is tied in the sense that the developing country is required to co-finance the public input. ${ }^{7}$ Two alternative assumptions are made regarding the objective of the donor country. First, we consider the case of an altruistic donor, which chooses the amount of aid so that it maximizes the joint, its own and the recipient country's, level of welfare. Second, we consider the case of a self-interested donor, which chooses the amount of aid so as to maximize its individual level of welfare. ${ }^{8}$ We find, among other things, that the best response of the developed donor country is to increase aid as the co-financing rate from the recipient country increases. When the immigration cost decreases, it is welfare improving for the donor country to increase aid. ${ }^{9}$

\section{The Model}

We develop a two-country, Home and Foreign, general equilibrium model of international migration, foreign aid and of pubic inputs. For the purposes of our analysis we let Home be a developed aid-donating labor-importing, host-country, while Foreign is assumed to be a developing aid-receiving labor-exporting, sourcecountry.

\footnotetext{
${ }^{7}$ In models of international migration where international transfers to the source country are used as a migration deterrent mechanism (eg., Myers and Papageorgiou, 2000), aid is lump-lump distributed to local residents in order to improve their welfare. For example, EU implements the co-financing policy considered here, within its regional policy where countries that get aid are required to finance a certain percentage of the cost of the project.

${ }^{8}$ The issue of an altruistic vs. a self-interested donor country is raised, among others and in different context, by Lahiri and Raymondos-Møller (1997).

${ }^{9}$ The US has used foreign aid to developing countries, eg., Haiti and Mexico, as means of curbing international migration by improving living and working conditions at the origin, rather than by adopting costly immigration controls at its borders.
} 
Other factors of production, such as capital and land, for simplicity, are assumed to be internationally immobile, and thus their national supplies are equal to their fixed endowments in each country. International trade in goods is free and the two countries are small in world commodity markets. As a result, labor flows between them do not affect world prices of goods. However, the two countries are large in labor markets and labor mobility between them it is not costless. ${ }^{10}$

We assume that each country comprises two classes of identical within each class individuals. Capitalists who possess one unit of labor and other factors of production, and workers who only possess one unit of labor. We further assume that migration between the two countries is from the class of workers and is permanent in the sense that immigrants do not remit any of their income earnings back to the source country, and that their utility is part of the host country's welfare. ${ }^{11}$ We proceed to develop the two-country model of international migration, foreign aid and public inputs. Star variables refer to Foreign.

Let $N=L+H$ be Home's total population, where $(L)$ and $(H)$ respectively denote the number of workers and capitalists in the country. Similarly, $N^{*}=L^{*}+H^{*}$ denotes Foreign's total population. Because of the assumptions of the model $d L=-d L^{*}$ and $d H=d H^{*}=0$. Let $R(L)$ denote Home's maximum value of gross domestic product (GDP), given constant world commodity prices and fixed endowments of all other factors. These variables are omitted from the GDP function since they do not affect the analysis. The $R(L)$ function is assumed strictly concave in $L$ (ie., $R_{L L}<0$ ). ${ }^{12}$ Its partial derivative with respect to $L$ (ie., $R_{L}$ ) is the marginal revenue product of labor, which in equilibrium equals the country's rate of return to the factor.

We denote by $e^{j}\left(u^{j}\right), j=L, H$ the minimum expenditure function of a representative worker $(L)$ or of a capitalist $(H)$ required to achieve a level of utility

\footnotetext{
${ }^{10}$ This asymmetric treatment of the two countries in world commodity and factor (labor) markets is adopted since in the present model the issue is international migration rather than international trade. Practically, however, the model could resemble a case of an "old", pre-accession, EU donor country (eg., Germany, France) and of a "new", post-accession, one (eg., Poland, Slovakia), where both may be considered price takers in international goods markets but are affected by their bilateral migration flows.

${ }^{11}$ This is an analytical simplifying assumption of the model. Emigrants often do remit part of their income earnings back to their home-source country, and source countries do care about the welfare of their permanent emigrants.

${ }^{12}$ In a standard two-good two-factor Heckscher-Ohlin model it is known that $R_{L L}=0$.
} 
$u^{j}$ given at the constant world commodity prices. Its derivative $e_{u}^{j}$ denotes the reciprocal of the marginal utility of income. Home's public sector (the government) levies income taxes at a rate $(\rho)$. A portion of this tax revenue is assumed to finance aid of the amount $(T)$ to Foreign, and the remaining portion is equally distributed to the country's residents as transfer payments. ${ }^{13}$

The country's income-expenditure identity requires that total spending by its residents must equal net income from production minus the transfer payment to Foreign. That is,

$$
L e^{L}\left(u^{L}\right)+H e^{H}\left(u^{H}\right)=R(L)-T .
$$

The income-expenditure identity of a Home's representative worker requires that aggregate expenditure equals net income from labor services plus net transfer payments received from the government in a lump-sum fashion. That is,

$$
e^{L}\left(u^{L}\right)=(1-\rho) R_{L}(L)+\frac{\rho R(L)-T}{N} .
$$

In Foreign, production of goods by the private sector, aside of the use of primary factors (eg., labor, capital, land), also makes use of a public input (z). For the purposes of our analysis it is assumed that the quantity $\left(z^{*}\right)$ of the public input is imported by the country's public sector, purchased in international markets at a constant price $p_{Z} \cdot{ }^{14}$ Then, the government provides $z$, at no cost, to the private sector producers for the production of the traded goods. ${ }^{15}$ Thus, we define $R^{*}\left(L^{*}, z^{*}\right)$ to be Foreign's GDP function at variable supplies of labor and public input, given the fixed endowments of all other primary factors and the constant commodity prices. The latter variables, for the reasons previously noted, are omitted from the GDP function. By the

\footnotetext{
${ }^{13}$ It is assumed that all the residents of the country have the same access to the services provided by the government such as health, education etc.

${ }^{14}$ There exists a broad international trade literature on local production of public inputs along with the production of private goods (eg., Abe 1990, Feehan 1992). Here, and without much loss of generality we depart from this standard analytical framework in order to highlight more clearly the results of the paper.

${ }^{15}$ Chao and Yu (1999), in a different context, apply the idea of co-financing the purchases of public goods through foreign aid and appropriated matching funds by the recipient country.
} 
properties of the GDP function $R_{z}^{*}\left(=\partial R^{*} / \partial z^{*}\right)$ denotes the marginal revenue product of the public input, and is positive and diminishing (ie., $R_{z^{*} z^{*}}^{*}<0$ ). It is further assumed that labor and the public input are complements in production, that is, an increase in the level of the public input $z^{*}$ increases the marginal revenue product of labor (ie., $R_{L z^{*}}^{*}>0$ ).

Imports $z^{*}$ of the public input by Foreign's government are purchased at a fix world price. Moreover, these imports are financed through foreign aid received from Home, and by appropriating matching funds, ${ }^{16}$ at a rate $\gamma>0$ (ie., $\gamma T$ ) by Foreign's government to co-finance the purchases of the imported public inputs. ${ }^{17}$ These matching funds are raised through non-distortionary lump-sum taxes. For simplicity we assume that these taxes solely burden the country's capitalists, while no taxes of any type are levied on the class of workers. ${ }^{18}$ Assuming that Foreign's government maintains a balanced budget, the public sector's budget constraint is given by:

$$
p_{z} z^{*}=(1+\gamma) T
$$

The income-expenditure identity for Foreign requires that total spending by that country's residents must equal income from production minus the lump-sum taxes required to finance part of the cost of the imported public input, i.e., $\gamma T$. That is,

$$
L^{*} e^{L^{*}}\left(u^{L^{*}}\right)+H^{*} e^{H^{*}}\left(u^{H^{*}}\right)=R^{*}\left(L^{*}, z^{*}\right)-\gamma T .
$$

Recall that no taxes of any type are levied by the Foreign's public sector on the class of workers neither do they receive any transfer from the government. Thus, the income-expenditure identity of a representative worker requires that his aggregate spending equals his wage, which equals his marginal revenue product. Thus,

\footnotetext{
${ }^{16}$ In reality, eg., aid in the context of EU regional development policy, co-financing on the part of the recipient countries is mandatory for aid to be allotted to them. In our model we assume that the recipient country voluntarily contributes, along with foreign aid, to the financing of the public input.

${ }^{17}$ Michael and Hatzipanayotou (2001) examine the welfare effects of migration when revenue from indirect taxes is used to finance the provision of public goods.

${ }^{18}$ This is a simplifying assumption to facilitate the workings of the model. Actually, however, it is not far from reality since the potential immigrants are amongst the poorer groups of the country whose income is either about equal or below the minimum taxable income.
} 


$$
e^{L^{*}}\left(u^{L^{*}}\right)=R_{L}^{*}\left(L^{*}, z^{*}\right)
$$

As previously noted, migration is associated with the class of workers, it is permanent and the labor markets equilibrium requires the equalization of the net income of the factor in the two countries. It is assumed, however, that migration is not costless. That is, immigrants must incur fixed monetary and other costs $(c)$ in moving from one country to the other. ${ }^{19}$ Thus, labor market equilibrium is achieved when:

$$
R_{L^{*}}^{*}\left(L^{*}, z^{*}\right)=(1-\rho) R_{L}+\frac{\rho R-T}{N}-c
$$

The left-hand side of equation (6) is the marginal revenue product of labor in Foreign, the labor-exporting country. The right-hand side term is the income, net of immigration costs earned by an immigrant worker in Home, the labor-importing country. ${ }^{20}$

Equations (1), (2) and (4)-(6) comprise a system of five equations in terms of levels of individual welfare (ie., $u^{j}, u^{j^{*}}, j=L, H$ ), and level of employment (ie., $\left.L\left(L^{*}\right)\right)$ in the two countries. The policy instruments in our analysis are, for Home, the level of foreign aid $(T)$, and for Foreign the matching rate $(\gamma)$ of co-financing the purchases of the imported public input $\left(z^{*}\right)$. The costs of migration $(c)$ constitute an exogenous parameter to the model. To pursue the welfare analysis we assume an egalitarian social welfare function with weights the reciprocal of social marginal utility of income of each individual in the two countries. Thus, changes in social welfare are denoted in Home by $d W=L e_{u}^{L} d u^{L}+H e_{u}^{H} d u^{H}$, and in Foreign by $d W^{*}=L^{*} e_{u}^{L^{*}} d u^{L^{*}}+H^{*} e_{u}^{H^{*}} d u^{H^{*}}$. Differentiating equations (1), (4) and (6) and using equations (2), (3) and (5) we obtain:

$$
d W=-\Lambda_{L} d L-d T
$$

\footnotetext{
${ }^{19}$ The immigration cost can be monetary but it can include other costs associated with legal or illegal immigration such as cost of moving, settlement, adjustments cost etc.
} 


$$
\begin{aligned}
& d W^{*}=\frac{T}{p_{z}}\left(R_{z^{*}}^{*}-p_{z}\right) d \gamma+\frac{\left[R_{z^{*}}^{*}+\gamma\left(R_{z^{*}}^{*}-p_{z}\right)\right]}{p_{z}} d T, \\
& \Delta d L=\frac{T}{p_{z}} R_{L z^{*}}^{*} d \gamma+\frac{\left[p_{z}+(1+\gamma) N R_{L^{*} z^{*}}^{*}\right]}{p_{z} N} d T+d c,
\end{aligned}
$$

where $\Lambda_{L}=\left(\rho\left(R-N R_{L}\right)-T\right) / N, \Delta=\left[\Phi-\left(\Lambda_{L} / N\right)\right]$ and $\Phi=(1-\rho) R_{L L}+R_{L L}^{*}(<0)$. For a representative worker $\Lambda_{L}$, denoting net transfer payments per worker in Home is positive implying that the representative worker is a net fiscal beneficiary. That is, a worker receives $(\rho R-T) / N$ transfer payments that exceed the amount of income taxes $\rho R_{L}$ that he pays. By the properties of the GDP function and the above assumption regarding $\Lambda_{L}, \Delta$ is negative.

Equation (7) captures the standard direct worsening effect of foreign aid on the donor country's (Home) welfare. Also, an increase in the local labor force, due to migration, exerts a negative impact on Home's welfare since it is assumed that workers are net fiscal beneficiaries (ie., $\Lambda_{L}$ is positive). Equation (8) indicates that if the marginal revenue product of the public input (ie., $R_{z^{*}}^{*}$ ) is greater than its fixed price (i.e., $\mathrm{p}_{\mathrm{z}}$ ), ${ }^{21}$ then an increase in the rate $(\gamma)$ or in the amount of aid $(T)$, which both raise total funds available for public input spending, raises welfare in Foreign, the aid receiving country. ${ }^{22}$ Finally, equation (9) captures the effects on Home's labor supply, due to migration, from changes in the policy variables and the cost of migration. It indicates that Home's labor supply falls either with an increase in the costs of migration $(c)$ and/or with an increase in Foreign's matching funds rate $(\gamma)$. Intuitively, an increase in the rate $(\gamma)$ raises purchases of $z^{*}$ which in turn raises the marginal revenue product of labor, and thus the equilibrium wage rate, in Foreign. This increase in Foreign's wage rate reduces the number of emigrants from Foreign or causes return migration from Home to Foreign. In either case, the higher $(\gamma)$ reduces Home's labor supply. An increase in the amount of aid entails a negative impact on

\footnotetext{
${ }^{20} \mathrm{By}$ and large, the literature on international migration perceives legal migration as costless and only illegal immigrants bearing a cost of gaining entry to the host country.

${ }^{21}$ We say that if $R_{z}^{*}>(<) p_{z}$, then there is under-(over) provision of the public input.

${ }^{22}$ Note that because of the income-expenditure specification for Foreign's workers, as stated by equation (5), changes in the country's labour force (ie., $d L^{*}=-d L$ ) do not directly affect its welfare.
} 
Home's labor supply. On the one hand, higher aid to Foreign exerts a negative impact on the donor country's labor supply since it lowers domestic workers net income earnings by decreasing the net income transfers. On the other hand, as in the case of a higher matching rate $(\gamma)$, an increase in the amount of aid reduces Home's labor supply since it increases wages in the Foreign, given that labor and the public input are complements in Foreign's production.

\section{Aid, International Migration and Welfare}

In this section, we derive the effects on each country's welfare from changes in the policy instruments or the exogenous variable. Substituting equation (9) into (7) and using equation (8), changes in Home and Foreign's welfare due to changes in the variables $\mathrm{T}$, $\mathrm{c}$ and $\gamma$, accounting for migration induced changes in labor supplies, are given as follows:

$$
\begin{aligned}
& \Delta d W=A_{T} d T+A_{\gamma} d \gamma+A_{c} d c, \text { and } \\
& \Delta d W^{*}=B_{T} d T+B_{\gamma} d \gamma,
\end{aligned}
$$

where, $\quad A_{T}=-\Delta-\left(p_{z} N\right)^{-1} \Lambda_{L}\left[p_{z}+(1+\gamma) N R_{L^{*} z^{*}}^{*}\right], \quad A_{\gamma}=-p_{z}^{-1} T \Lambda_{L} R_{L^{*} z^{*}}^{*}, \quad A_{c}=-\Lambda_{L}$, $B_{T}=p_{z}^{-1} \Delta\left[R_{z^{*}}^{*}+\gamma\left(R_{z^{*}}^{*}-p_{z}\right)\right], B_{\gamma}=p_{z}^{-1} \Delta\left(R_{z^{*}}^{*}-p_{z}\right) T$, and $B_{c}=0$.

Equation (10) depicts the effects of changes in the policy instruments $T, \gamma$ and in the migration cost parameter $c$ on Home's welfare. The term $\Delta^{-1} A_{T}$ indicates that more aid to Foreign exerts a direct negative effect, and an indirect, labor supply, effect on the Home welfare. ${ }^{23}$ As we have seen, labor supply in Home falls as a result of aid, and thus aid may result to the so-called "transfer paradox" whereby it may improve Home's, the donor country, welfare if the indirect labor supply effects dominates the direct negative effect of aid. The term $\Delta^{-1} A_{\gamma}$ indicates that an increase in the matching rate of aid $(\gamma)$, increases employment in the Foreign since labor and the public input are complements in Foreign's production, reduces immigration in Home and thus increases its welfare, since immigrants are net fiscal beneficiaries.

\footnotetext{
${ }^{23}$ Note that combining equations (9) and (10) we can write $A_{T}=-\Delta\left(1+\Lambda_{L}(d L / d T)\right)$.
} 
Finally, a decrease in the cost of immigration unambiguously decreases Home's, the labor-importing country's, welfare since it causes inflow of net fiscal beneficiary workers. Equation (11) captures the effects of changes in $T, \gamma$ and $c$ on Foreign's welfare. Specifically, if there is under provision of the public input, then more aid or a higher matching rate $(\gamma)$ raises Foreign's welfare.

\subsection{Altruistic Donor}

In this subsection we assume that Home, the donor country, chooses the amount of aid $(T)$ so as to maximize the joint, ie., its own and the recipient Foreign's welfare. From equations (10) and (11), after some calculations we obtain:

$$
N p_{z} \Delta\left(\frac{d W}{d T}+\frac{d W^{*}}{d T}\right)=\Omega_{\mathrm{T}}=(1+\gamma) N \Phi\left(R_{z^{*}}^{*}-p_{z}\right)+\left(-\rho \lambda_{L}+\bar{T}\right)\left[(1+\gamma)\left(N R_{L^{*} z^{*}}^{*}+R_{z^{*}}^{*}\right)-\gamma p_{z}\right]
$$

where $\bar{T}=T / N$, and $\lambda_{L}=(R / N)-R_{L}$, which is positive since average income is higher than the wage rate. Setting $\Omega_{T}=0$, the optimal level of aid $\left(T_{\Omega}\right)$ maximizing the two countries joint welfare is given by

$$
T_{\Omega}=\left[\rho \lambda_{L}+\frac{(1+\gamma) N \Phi\left(p_{z}-R_{z^{*}}^{*}\right)}{(1+\gamma)\left(N R_{L^{*} z^{*}}^{*}+R_{z^{*}}^{*}\right)-\gamma p_{z}}\right] N
$$

The denominator of the right hand side term of equation (13) is always positive if the marginal revenue product of the public input is equal or greater than its unit cost (i.e., $R_{Z}^{*} \geq p_{z}$ ) (sufficient but not necessary condition). The numerator of the same term is not negative if $R_{z}^{*} \geq p_{z}$. If the recipient country choose $\gamma$ optimally to maximize its own welfare, equation (11) reveals that the recipient will chose $\gamma$ in such a way in order to equalize the marginal revenue product of the public input with its marginal cost (i.e., $R_{z}^{*}=p_{z}$ ). Thus, when the recipient country choose $\gamma$ to maximize its own welfare, then the optimum amount of aid chosen by the donor country to maximize the joint welfare is positive and is given as $T_{\Omega}=\rho N \lambda_{L}$. If, however, the recipient country for some reasons cannot choose $\gamma$ optimally and it is 
sub-optimally chosen, then $R_{z}^{*}>p_{z}$. In this case, the second term on the right hand side of equation (13) is positive, and thus, ceteris paribus, the amount of aid maximizing the two countries joint welfare is greater when the recipient country chooses the co-financing rate $\gamma$ sub-optimally compared to when it is chosen optimally. ${ }^{24}$ Intuitively, when $R_{z}^{*}=p_{z}$, and the donor country gives aid $\mathrm{T}$, the welfare of the recipient country increases by $\mathrm{T}$ and the donor's decreases by $\mathrm{T}$, which cancel each other. There is, however, an additional indirect effect via the increase in employment in the recipient country and thus a decrease in immigration in the donor country. Since immigrants are net fiscal beneficiaries, the reduction in immigration in the donor country increases its welfare by $\rho N \lambda_{L}$. The optimum amount of aid equals the gain in its welfare due to the reduction in the immigration. ${ }^{25}$ When the public input is sub optimally provided in the recipient country, then there is an additional positive effect on the welfare of the recipient country, since it finances the public input with aid and the marginal revenue product of the public input is greater than its marginal cost, i.e., $R_{z}^{*}>p_{z}$.

\subsection{The Nash equilibrium}

We now examine the choice of the instruments by the two countries, assuming that they behave non-cooperatively (Nash). Namely, we assume that Home, the donor labor-importing country decides on the amount of aid(T), and Foreign, the recipient labor-exporting country, chooses the matching rate $(\gamma)$ to foreign aid. For this, the first order conditions are given by:

$$
\begin{aligned}
& \Delta(d W / d T)=A_{T}=0, \text { and } \\
& \Delta\left(d W^{*} / d \gamma\right)=B_{\gamma}=0 .
\end{aligned}
$$

\footnotetext{
${ }^{24}$ Note that the recipient country never chooses $\gamma$ in such a way so that the public input is overprovided (i.e., $R_{z}^{*}<p_{z}$ ). If it does so, then by reducing $\gamma$ and thus the amount spend for public input, welfare increases and it will continue to increase until $R_{z}^{*}=p_{z}$.

${ }^{25}$ In this case substituting $T_{\Omega}$ into the migration equilibrium condition, equation (6), it reduces to $R_{L^{*}}^{*}=R_{L}-C$.
} 
Equations (14) and (15) simultaneously determine the Nash equilibrium values of $(T)$ and $(\gamma)$. In particular, from equation (15) we get that, given that the co-financing of aid by Foreign, is used to finance the purchases of the public input, the Nash equilibrium value of $(\gamma)$ requires that $R_{z^{*}}^{*}=p_{z}$. That is, the Nash equilibrium value of $(\gamma)$ leads to the provision of $z^{*}$ up to the point where its marginal revenue product is equal to its fixed world price. From equation (14) we obtain Home's, the donor country's, Nash equilibrium value of $(T)$ as follows:

$$
T=\left[\rho \lambda_{L}+\frac{\Phi p_{z}}{(1+\gamma) R_{L z^{*}}^{*}}\right] N .
$$

Equation (16) indicates that the Nash equilibrium value of $(T)$ can be positive or zero. $^{26}$ However, the likelihood for it to be positive increases with (i) the value of Foreign's co-financing rate $(\gamma)$, (ii) the higher degree of complementarity between labor and the public input in Foreign's production (i.e.,, $R_{L^{*} z^{*}}^{*}$ ), (iii) the difference between the average income and the marginal revenue product of labor in Home, ie., $\lambda_{L}$, and (iv) the Home's income tax rate $\rho$. Observing equations (13) and (16) it is easily verifiable, since $R_{z^{*}}^{*} \geq p_{z}$, that $\left(T_{\Omega}-T\right)>0$. That is, the amount of aid chosen to maximize the countries joint welfare is greater to its Nash equilibrium level.

\subsection{Aid, co-financing and the immigration cost.}

Having obtained the Nash equilibrium values of the policy instruments $(T)$ and $(\gamma)$, we examined how changes in the immigration cost affect the above Nash equilibrium values. Differentiating the best response or the reaction functions (14) and (15) we obtain:

$$
\begin{aligned}
& A_{T T} d T+A_{T \gamma} d \gamma=-A_{T C} d c, \quad \text { and } \\
& B_{\gamma T} d T+B_{\gamma \gamma} d \gamma=-B_{\gamma c} d c .
\end{aligned}
$$

\footnotetext{
${ }^{26}$ The two right-hand side terms of equation (16) are of opposite sign. The amount of aid, however, can only be non-negative.
} 
The expressions and signs of the coefficients in the above equations are given in the Appendix.

First, equations (17) and (18) can give the slope of each country's best response function. Specifically for Home and Foreign, respectively, we have:

$$
\left(\frac{d T}{d \gamma}\right)_{A_{T}=0}=-\frac{A_{T \gamma}}{A_{T T}} \quad \text { and } \quad\left(\frac{d T}{d \gamma}\right)_{B_{\gamma}=0}=-\frac{B_{\gamma \gamma}}{B_{\gamma T}} .
$$

Both expressions are of positive sign, i.e., both best response functions have positive slope, given the signs of the right-hand side terms as stated in section (B.1) of the Appendix. That is, when Foreign raises its co-financing rate $\gamma$ the best response for Home is to increase the amount of foreign aid. Likewise, the best response for Foreign, when Home raises the amount of aid, is to increase its co-financing rate $\gamma$. Moreover, invoking the stability condition of equations (A.2) of the Appendix, requiring that $\Omega>0$, then $-\left(A_{T \gamma} / A_{T T}\right)>-\left(B_{\gamma \gamma} / B_{\gamma T}\right)$.

Second, using equations (A.3) and (A.4) of the Appendix, the effect of an increase in the migration cost $(c)$ on the Nash equilibrium values of policy parameters $(T)$ and $(\gamma)$ is given as follows:

$$
\begin{aligned}
& \Omega \Delta^{2}\left(\frac{d T}{d c}\right)=-(1+\gamma) N R_{L z^{*}}^{*}\left[T \Delta R_{z^{*} z^{*}}^{*}\left(\rho N R_{L L}+\Lambda_{L}\right)+\left(N R_{L z^{*}}^{*} \Lambda_{L}\right)^{2}\right]<0, \text { and } \\
& \Omega \Delta^{2}\left(\frac{d \gamma}{d c}\right)=(1+\gamma) N R_{L z^{*}}^{*}\left[(1+\gamma) R_{z^{*} z^{*}}^{*}\left(\rho N R_{L L}+\Lambda_{L}\right)-R_{L z^{*}}^{*} \Lambda_{L}\left(1+(1+\gamma) N R_{L z^{*}}^{*}\right)\right]<0 .
\end{aligned}
$$

Equations (20) and (21) indicate that a decrease in the immigration cost (c) unambiguously increases the Nash equilibrium amount $(T)$ of aid by Home, and Foreign's matching rate to foreign aid $(\gamma)^{27}$. Intuitively, the reduction in the immigration cost causes an inflow of net fiscal beneficiary foreign workers which

\footnotetext{
${ }^{27}$ An explanation for the positive sign of the term $\Lambda_{L}+\rho N R_{L L}$ is provided by equation (A.1) in the Appendix.
} 
decreases Home welfare (i.e., the welfare of natives). Thus, Home has an incentive and it is beneficial for itself to provide more aid to Foreign in order to reduce immigration. When immigration costs rises, immigration falls and there is no incentive to provide more aid. In fact the same effect, ie., fewer immigrants, may be achieved with lower aid. Thus, if for some reason (e.g., due to greater economic integration), immigration cost is reduced, causing immigration, then it is beneficial for the Home, the donor, to provide more aid that in turn again reduces immigration. ${ }^{28}$ An increase in the immigration cost does not affect the welfare of the recipient country directly, but only indirectly, through the change in the behavior of the donor country. Thus, the reduction in the immigration cost, which causes the increase in aid by the donor, creates an incentive for the recipient country to increase the cofinancing rate $\gamma$ since this increase will increase even further the amount of aid.

\section{Concluding Remarks}

As it is well known, there are large differences in wages and government income transfers through the welfare system, between developed and developing countries. The recent technological and other developments and the globalization, on the one hand, have made people in the developing countries more aware of these discrepancies and on the other hand, have reduced the cost of migration (legal or illegal). As a consequence of the above, a large number of people from the developing countries are willing to migrate in the developed countries. The developed, host countries, however, are reluctant to accept large numbers of immigrants, especially with low skills. They are afraid that large number of immigrants will affect negatively their local labor markets and endanger their social welfare systems since the low skilled immigrant are expected to be net fiscal beneficiaries.

This paper builds a model that takes into account the above features. That is, we build a two-country model where migration is modeled from a developing-source country with no welfare system to a developed-host country with a comprehensive welfare system of income taxes and transfers from its more to its less affluent residents. Labor mobility between the two countries is not costless due to the existence of migration costs, and the developed country gives aid to the developing

\footnotetext{
${ }^{28}$ Myers and Papageorgiou (2000) in a model with illegal immigration have shown that when illegal immigrants have access to the public sector welfare system, then as the border control becomes more expensive some migration is permitted and foreign aid may be used to reduce migration pressure.
} 
country. This aid, along with local co-financing, by the developing country is used for the provision of a public input, which positively affects the marginal revenue product of labor. We consider the cases where aid by the donor country is chosen either in order to maximize the joint, its own and the recipient country's, welfare or in a noncooperative (Nash) way.

We demonstrate, among other things, that, first, the amount of aid maximizing the two countries joint welfare is greater when the recipient country chooses the cofinancing rate sub-optimally compared to when it is chosen optimally. Second, the amount of aid chosen to maximize the countries joint welfare is greater than its Nash equilibrium level. Moreover, if there is a reduction in the migration cost due to globalization or due to greater economic or political integration, then it is beneficial for the donor-host country to increase the Nash equilibrium amount of aid to the recipient-source country to co-finance its public infrastructure. For example, it will beneficial for the original 15 countries of the EU to increase aid to the new members through the EU regional policy or for the USA and Canada to give tied economic aid to Mexico for the co-financing of improvements in its infrastructure. ${ }^{29}$

\footnotetext{
${ }^{29}$ Another example is that of regional development transfers between two regions of the same country, e.g., former West Germany gives aid to former East Germany to finance the improvement in its infrastructure.
} 


\section{APPENDIX}

\section{The coefficients in equations (17) and (18) and their signs}

(I.a) The coefficients: Using the first order conditions $A_{T}=0$ and $B_{\gamma}=0$, and when differentiating $\mathrm{A}_{\mathrm{T}}=0$ we assume that the third derivatives of the revenue function are zero, we obtain:

$$
\begin{aligned}
& A_{T T}=\Delta^{-1} p_{z}^{-2} \rho(1+\gamma) N R_{L L} R_{L z^{*}}^{*}\left[p_{z}+N(1+\gamma) R_{L z^{*}}^{*}\right]>0, \\
& A_{T \gamma}=\Delta^{-1}(1+\gamma) N R_{L z^{*}}^{*{ }^{2}}\left[N \Lambda_{L}^{2}+T\left(\Lambda_{L}+\rho N R_{L L}\right)\right]<0, \\
& A_{T C}=\Delta^{-1} p_{z} N(1+\gamma) R_{L z^{*}}^{*}\left(\Lambda_{L}+\rho N R_{L L}\right)<0, \\
& B_{\gamma T}=\left(\Delta p_{z}\right)^{-1}\left[(1+\gamma)\left(\Delta R_{z^{*} z^{*}}^{*}-p_{z} N R_{L z^{*}}^{*^{2}}\right)-p_{z}^{2} R_{L z^{*}}^{*}\right]>0, B_{\gamma \gamma}=\left(\Delta p_{z}\right)^{-1} T\left(\Delta R_{z^{*} z^{*}}^{*}-p_{z} N R_{L z^{*}}^{* 2}\right)<0, \\
& B_{\gamma c}=-\left(\Delta p_{z}\right)^{-1} N R_{L z^{*}}^{*}>0 .
\end{aligned}
$$

(I.b) The signs of the coefficients:

(i) $A_{T T}$ and $B_{\gamma \gamma}$ are signed based on the welfare maximization problem of each country. Namely, Home chooses $(T)$ and Foreign chooses $(\gamma)$, non-cooperatively, so that social welfare is maximized. Following suitable calculations this implies that for Home $\left(d^{2} W / d T^{2}\right)=\Delta^{-1} A_{T T}$ must be negative, and for Foreign $\left(d^{2} W^{*} / d \gamma^{2}\right)=T B_{\gamma \gamma}$ must be negative. For these results the necessary condition is that $A_{T T}>0$ and $B_{r}<0$, respectively.

(ii) The sign of the expression $A_{T \gamma}$ and of $A_{T C}$ is determined by the sign of the right-hand side term $\left(\Lambda_{L}+\rho N R_{L L}\right)$. Based on the assumptions of the model, the latter term is signed as follows:

Let $\Gamma=\frac{\rho N-T}{N}-\rho R_{L}$ be the net fiscal benefit accruing to a representative worker in Home, the host country. Differentiating this expression with respect to $(L)$ captures the migration induced change in this per-capita net fiscal benefit. That is:

$$
\frac{d \Gamma}{d L}=\frac{d}{d L}\left(\frac{\rho R-T}{N}-\rho R_{L}\right)=-\left(\Lambda_{L}+\rho N R_{L L}\right) .
$$


Assuming that $(d \Gamma / d L)$ is negative, ie., the net fiscal benefit of a worker in Home falls as more immigrants enter into the country, it requires $\Lambda_{L}+\rho N R_{L L}$ is positive. Based on this, $A_{T \gamma}$ and $A_{T C}$ are of negative sign.

(iii) The coefficient $B_{\gamma T}$ is signed as follows: Equations (17) and (18) in a matrix form are given as:

$$
\left[\begin{array}{ll}
A_{T T} & A_{T \gamma} \\
B_{\gamma T} & B_{\gamma \gamma}
\end{array}\right]\left[\begin{array}{l}
d T \\
d \gamma
\end{array}\right]=\left[\begin{array}{l}
-A_{T c} \\
-B_{\gamma c}
\end{array}\right] d c,
$$

where the determinant of the matrix of the coefficients of $d T$ and $d \gamma$ is $\Omega=A_{T T} B_{\gamma \gamma}-A_{T \gamma} B_{\gamma T}$. Stability requires that $\Omega$ is positive. Given the signs of $A_{T T}, A_{T \gamma}$ and $B_{\gamma \gamma}$, the necessary condition for $\Omega>0$ is that $B_{\gamma T}>0$.

(iv) Lastly, $B_{\gamma c}>0$ is based on our assumption that $R_{L z^{*}}^{*}>0$.

\section{The effects of changes in $(c)$ on $(T)$ and $(\gamma)$ :}

Equations (A.1) yield the following results:

$$
\begin{aligned}
& \Omega\left(\frac{d T}{d c}\right)=-A_{T c} B_{\gamma \gamma}+A_{\gamma T} B_{\gamma c}, \text { and } \\
& \Omega\left(\frac{d \gamma}{d c}\right)=-A_{T T} B_{\gamma c}+B_{\gamma T} A_{T c} .
\end{aligned}
$$




\section{References}

Abe, K., 1990, A public input as a determinant of trade, Canadian Journal of Economics 23, 400-407.

Bauer, T. and A. Kunze, 2004, The demand for high-skilled workers and immigration policy, CEPR Discussion paper No. 4274.

Carrington, W.J. and E. Detraciaghe, 1998, How big is the Brain Drain? International Monetary Fund W.P. 98/102.

Chao, C-C., and E. Yu, 1999, Foreign aid, the environment, and welfare, Journal of Development Economics 59, 553-564.

Chao, C-C. and E. Yu, 2002, Immigration and welfare for the host economy with imperfect competition, Journal of Regional Science 42, 327-338.

Epstein, S. Gil and Arye L. Hillman, 2003, Unemployed immigrants and voter sentiment in the welfare state, Journal of Public Economics 87, 1641-1655.

Feehan, J., 1992, The optimal revenue tariff for public input provision, Journal of Development Economics 38, 221-231.

Kondoh, K., 1999, Permanent migrants and cross-border workers: The effects on the host country, Journal of Regional Science 39, 467-478.

Lahiri, S. and P. Raymondos-Møller, 1997, Competition for aid and trade policy, Journal of International Economics 43, 369-385.

Michael, S. M., 2003, International migration, income taxes and transfers: a welfare analysis. Journal of Development Economics 72, 401-411.

Michael, S. M. and P. Hatzipanayotou, 2001, Welfare effects of migration in societies with indirect taxes, income transfers and public good provision. Journal of Development Economics 64, 1-24. 
Myers, G. and Y. Papageorgiou, 2000, Immigration control and the welfare state, Journal of Public Economics 75, 183-207.

Quibria, M. G., 1988, On generalizing the economic analysis of international migration: a note. Canadian Journal of Economics 21, 874-876.

Razin, A. and E. Sadka, 2004, Welfare migration: Is the net fiscal burden a good measure of its economic impact on the welfare of the native-born population, CESIFO working paper No. 1273.

Razin, A., E. Sadka and P. Swagel, 2002, Tax burden and migration: a political economy theory and evidence, Journal of Public Economics 85, 167-190.

Sandmo, A. and D. Wildasin, 1999, Taxation, migration, and pollution, International Tax and Public Finance 6, 39-59.

Sinn, H-W., 2004, Introduction, Social Union, Migration and the Constitution: Integration at Risk, CES-ifo Forum, Autumn Vol. 5, No. 3, 4-11.

Wildasin, D., 2004, Economic integration and the welfare state, in Social Union, Migration and the Constitution: Integration at Risk, CES-ifo Forum, Autumn Vol. 5, No. 3, 19-26.

Wildasin, D., 1994, Income redistribution and migration. Canadian Journal of Economics 27, 637-656.

Wong, K.-Y., 1985, The economic analysis of international migration: a generalization. Canadian Journal of Economics 18, 357-362. 


\section{CESifo Working Paper Series}

(for full list see www.cesifo-group.de)

1433 George Economides and Apostolis Philippopoulos, Should Green Governments Give Priority to Environmental Policies over Growth-Enhancing Policies?, March 2005

1434 George W. Evans and Seppo Honkapohja, An Interview with Thomas J. Sargent, March 2005

1435 Helge Berger and Volker Nitsch, Zooming Out: The Trade Effect of the Euro in Historical Perspective, March 2005

1436 Marc-Andreas Muendler, Rational Information Choice in Financial Market Equilibrium, March 2005

1437 Martin Kolmar and Volker Meier, Intra-Generational Externalities and InterGenerational Transfers, March 2005

1438 M. Hashem Pesaran and Takashi Yamagata, Testing Slope Homogeneity in Large Panels, March 2005

1439 Gjermund Nese and Odd Rune Straume, Industry Concentration and Strategic Trade Policy in Successive Oligopoly, April 2005

1440 Tomer Blumkin and Efraim Sadka, A Case for Taxing Education, April 2005

1441 John Whalley, Globalization and Values, April 2005

1442 Denise L. Mauzerall, Babar Sultan, Namsoug Kim and David F. Bradford, Charging $\mathrm{NO}_{x}$ Emitters for Health Damages: An Exploratory Analysis, April 2005

1443 Britta Hamburg, Mathias Hoffmann and Joachim Keller, Consumption, Wealth and Business Cycles in Germany, April 2005

1444 Kohei Daido and Hideshi Itoh, The Pygmalion Effect: An Agency Model with Reference Dependent Preferences, April 2005

1445 John Whalley, Rationality, Irrationality and Economic Cognition, April 2005

1446 Henning Bohn, The Sustainability of Fiscal Policy in the United States, April 2005

1447 Torben M. Andersen, Is there a Role for an Active Fiscal Stabilization Policy? April 2005

1448 Hans Gersbach and Hans Haller, Bargaining Power and Equilibrium Consumption, April 2005 
1449 Jerome L. Stein, The Transition Economies: A NATREX Evaluation of Research, April 2005

1450 Raymond Riezman, John Whalley and Shunming Zhang, Metrics Capturing the Degree to which Individual Economies are Globalized, April 2005

1451 Romain Ranciere, Aaron Tornell and Frank Westermann, Systemic Crises and Growth, April 2005

1452 Plutarchos Sakellaris and Focco W. Vijselaar, Capital Quality Improvement and the Sources of Growth in the Euro Area, April 2005

1453 Kevin Milligan and Michael Smart, Regional Grants as Pork Barrel Politics, April 2005

1454 Panu Poutvaara and Andreas Wagener, To Draft or not to Draft? Efficiency, Generational Incidence, and Political Economy of Military Conscription, April 2005

1455 Maurice Kugler and Hillel Rapoport, Skilled Emigration, Business Networks and Foreign Direct Investment, April 2005

1456 Yin-Wong Cheung and Eiji Fujii, Cross-Country Relative Price Volatility: Effects of Market Structure, April 2005

1457 Margarita Katsimi and Thomas Moutos, Inequality and Relative Reliance on Tariffs: Theory and Evidence, April 2005

1458 Monika Bütler, Olivia Huguenin and Federica Teppa, Why Forcing People to Save for Retirement may Backfire, April 2005

1459 Jos Jansen, The Effects of Disclosure Regulation of an Innovative Firm, April 2005

1460 Helge Bennmarker, Kenneth Carling and Bertil Holmlund, Do Benefit Hikes Damage Job Finding? Evidence from Swedish Unemployment Insurance Reforms, May 2005

1461 Steffen Huck, Kai A. Konrad and Wieland Müller, Merger without Cost Advantages, May 2005

1462 Louis Eeckhoudt and Harris Schlesinger, Putting Risk in its Proper Place, May 2005

1463 Hui Huang, John Whalley and Shunming Zhang, Trade Liberalization in a Joint Spatial Inter-Temporal Trade Model, May 2005

1464 Mikael Priks, Optimal Rent Extraction in Pre-Industrial England and France - Default Risk and Monitoring Costs, May 2005

1465 François Ortalo-Magné and Sven Rady, Heterogeneity within Communities: A Stochastic Model with Tenure Choice, May 2005

1466 Jukka Pirttilä and Sanna Tenhunen, Pawns and Queens Revisited: Public Provision of Private Goods when Individuals make Mistakes, May 2005 
1467 Ernst Fehr, Susanne Kremhelmer and Klaus M. Schmidt, Fairness and the Optimal Allocation of Ownership Rights, May 2005

1468 Bruno S. Frey, Knight Fever - Towards an Economics of Awards, May 2005

1469 Torberg Falch and Marte Rønning, The Influence of Student Achievement on Teacher Turnover, May 2005

1470 John Komlos and Peter Salamon, The Poverty of Growth with Interdependent Utility Functions, May 2005

1471 Hui Huang, Yi Wang, Yiming Wang, John Whalley and Shunming Zhang, A Trade Model with an Optimal Exchange Rate Motivated by Current Discussion of a Chinese Renminbi Float, May 2005

1472 Helge Holden, Lars Holden and Steinar Holden, Contract Adjustment under Uncertainty, May 2005

1473 Kai A. Konrad, Silent Interests and All-Pay Auctions, May 2005

1474 Ingo Vogelsang, Electricity Transmission Pricing and Performance-Based Regulation, May 2005

1475 Spiros Bougheas and Raymond Riezman, Trade and the Distribution of Human Capital, June 2005

1476 Vesa Kanniainen, Seppo Kari and Jouko Ylä-Liedenpohja, The Start-Up and Growth Stages in Enterprise Formation: The "New View" of Dividend Taxation Reconsidered, June 2005

1477 M. Hashem Pesaran, L. Vanessa Smith and Ron P. Smith, What if the UK had Joined the Euro in 1999? An Empirical Evaluation Using a Global VAR, June 2005

1478 Chang Woon Nam and Doina Maria Radulescu, Effects of Corporate Tax Reforms on SMEs' Investment Decisions under the Particular Consideration of Inflation, June 2005

1479 Panos Hatzipanayotou, Sajal Lahiri and Michael S. Michael, Globalization, CrossBorder Pollution and Welfare, June 2005

1480 John Whalley, Pitfalls in the Use of Ad valorem Equivalent Representations of the Trade Impacts of Domestic Policies, June 2005

1481 Edward B. Barbier and Michael Rauscher, Trade and Development in a Labor Surplus Economy, June 2005

1482 Harrie A. A. Verbon and Cees A. Withagen, Tradable Emission Permits in a Federal System, June 2005

1483 Hendrik Hakenes and Andreas Irmen, On the Long-Run Evolution of Technological Knowledge, June 2005 
1484 Nicolas Schmitt and Antoine Soubeyran, A Simple Model of Brain Circulation, June 2005

1485 Carsten Hefeker, Uncertainty, Wage Setting and Decision Making in a Monetary Union, June 2005

1486 Ondřej Schneider and Jan Zápal, Fiscal Policy in New EU Member States - Go East, Prudent Man!, June 2005

1487 Christian Schultz, Virtual Capacity and Competition, June 2005

1488 Yvan Lengwiler and Elmar Wolfstetter, Bid Rigging - An Analysis of Corruption in Auctions, June 2005

1489 Johannes Becker and Clemens Fuest, Does Germany Collect Revenue from Taxing Capital Income?, June 2005

1490 Axel Dreher and Panu Poutvaara, Student Flows and Migration: An Empirical Analysis, June 2005

1491 Bernd Huber and Marco Runkel, Interregional Redistribution and Budget Institutions under Asymmetric Information, June 2005

1492 Guido Tabellini, Culture and Institutions: Economic Development in the Regions of Europe, July 2005

1493 Kurt R. Brekke and Michael Kuhn, Direct to Consumer Advertising in Pharmaceutical Markets, July 2005

1494 Martín Gonzalez-Eiras and Dirk Niepelt, Sustaining Social Security, July 2005

1495 Alfons J. Weichenrieder, (Why) Do we need Corporate Taxation?, July 2005

1496 Paolo M. Panteghini, S-Based Taxation under Default Risk, July 2005

1497 Panos Hatzipanayotou and Michael S. Michael, Migration, Tied Foreign Aid and the Welfare State, July 2005 